\title{
Housing Affordability by Federal Civil Servants in Minna, Nigeria: Emerging Issues
}

\author{
Ogunbajo A. Rukaiyat ${ }^{1}$, Suleiman Yakubu ${ }^{2}$, Fabunmi O. Foluke ${ }^{1} \&$ Ojetunde Ismail ${ }^{1}$ \\ ${ }^{1}$ Department of Estate Management and Valuation, Federal University of Technology, Minna, Nigeria \\ ${ }^{2}$ National Drug Law Enforcement Agency, Minna, Nigeria \\ Correspondence: Ogunbajo A. Rukaiyat, Department of Estate Management and Valuation, School of \\ Environmental Technology, Federal University of Technology, Minna, Nigeria. E-mail: \\ rukky.adeola@futminna.edu.ng
}

Received: October 10, 2014 Accepted: November 20, $2014 \quad$ Online Published: February 20, 2015

doi:10.5539/jms.v5n1p90 URL: http://dx.doi.org/10.5539/jms.v5n1p90

\begin{abstract}
In Nigeria, the 1999 constitution recognises housing as a fundamental human right; hence it is imperative that Nigerians have access to decent and comfortable accommodation at affordable costs. This study examined housing affordability by Federal Civil Servants in Minna by analysing the average annual emoluments of federal civil servants and the annual rental values of houses occupied by them, and subsequently established the percentage of annual income spent on rent. A total of 200 federal civil servants spread across all grade levels were sampled. Simple descriptive statistic, likert scale, relative index and pearson product moment correlation were used to analyse collected data. Findings showed that federal civil servants in the study area spend between $7.3 \%$ and $23.8 \%$ of their annual income on rents. The study also revealed that civil servants' level of income having a relative index of 0.96 is the major factor influencing the choice of residential accommodation by federal civil servants in the study area.It further revealed a strong positive correlation between their annual income and rental values of residential properties occupied by them. The sampled respondents expressed varied levels of satisfaction with the houses they occupy, with as much as $59 \%$ being unsatisfied with their rented housing units; these were attributed to poor housing quality, small sizes of housing units and densely populated neighbourhoods, among others. Housing Affordability Index was also adopted and used to determine housing affordability levels in the study area.The study recommended a home ownership scheme to enable federal civil servants purchase or build their own houses and pay conveniently because all respondents desired to own their own houses.
\end{abstract}

Keywords: housing, affordabiliy, rents, civil servants, income

\section{Introduction}

Man as a social being have needs and among these needs, three have been identified as basic and important. Shelter is one of them which provide covering from harsh environmental factors such as sunshine, wind, rainfall, humidity, frost and other forms of precipitation. Although, housing is an integral part of human settlement that fulfils basic need and has a profound impact on the quality of life, health, welfare, as well as productivity of man; large proportion of urban residents in developing countries do not have access to decent housing at affordable cost (Ibem \& Amole, 2010). As a result of this, inadequate housing has become a challenge that has continued to receive attention from governments, professionals, developers and individuals in most developing countries (Ibem \& Amole, 2010). As observed by Mitlin and Satterthwaite (2007) and quoted in Ayeniyo (2011), by year 2000, some 900 million urban dwellers in low and middle income households worldwide were "living in poverty" suffering from poor quality housing, insecure tenure and/or inadequate basic services.

Housing affordability is an issue of ability and willingness of the householder to back up his or her housing demand with the required financial resources (Egunjobi, 1994; Jinadu, 2007). It has been argued that a maximum of $30 \%$ of household income spent on housing be used as a yard stick for measuring housing affordability across Europe and elsewhere (Andrews, 1998; Aribigbola, 2011; Pittini, 2012).However, what is termed affordability problem in a given place or nation might not be applicable in other places and this is for no other reason but for the dynamics in economic and social variations.Meanwhile, the increase in the prices of conventional building materials which are imported and the fluctuating economy is contributing to the ailing problem of housing affordability (Gbadeyan, 2011). Aribigbola (2013) and Aribigbola \& Ayeniyo (2012) haven reviewed past 
housing policies explained that the Nigerian housing policy was basically aimed at providing affordable housing for Nigerians but this has not been successfully implemented.

In the past few years, Minna has been experiencing a high rate of urbanization and high population growth owing to the presence of a number of federal government establishments. A direct result of this is an increase in demand for housing by the staff of these establishments. This study is necessary to assess the impact of the new minimum wage being implemented by the Federal Government on Federal Civil Servants' ability to afford decent accommodation. The new minimum wage aimed at improving the working and living conditions of workers at the federal level, thus, an assessment of housing affordability by federal civil servants in Minna, considering their new income became imperative in order to adequately report the current affordability situation in the state capital.

\section{Indices for Measuring Housing Affordability}

Lau (2001) explained that three basic approaches have been identified for measuring housing affordability. These are normative, behavioural and subjective approaches.

\section{i. Normative approach}

Normative measurement defines housing affordability in terms of certain threshold values, that is, a household is experiencing affordability problem if the amount spent on housing with its respective income exceeds the benchmark rate. Lau (2001) submitted that the normative approach is the most developed of the various approaches and this embrace different measuring strategies such as: Rent-to- income ratio (RIR), Mortgage-to-income ratio (MIR) and House Price-to-income ratio (PIR). This is further buttressed by the earlier statement of Andrew (2008) and adopted by Aribigbola (2011) that "affordable housing" is that which costs no more than $30 \%$ of the income of the occupant's household.

\section{ii. Behavioural approach}

Peoples' housing consumption behaviour can also be used to measure housing affordability, that is, how much households choose to spend on housing with their respective incomes and characteristics. This means, how people view housing and what they spend on it should be given more consideration instead of setting a standard. Lau (2001) explained this as a better way of assessing housing affordability given adequate empirical data.

\section{iii. Subjective approach}

A completely different way to addressing affordability is taking into account the people's view on affordability and checking it against their financial positions as well as other quantitative indicators (Lau, 2001).

Ndubueze (2009) mentioned two other approaches to measuring affordability which are the basic non-cost approach and the quality adjusted approach. In his explanation, the basic non-cost approach otherwise known as the 'residual income' based approach or 'shelter poverty' approach,is the ability of a household to pay due to its sensitivity to the impact of housing cost on the capacity of the household to meet essential non-housing costs. On the other hand, the quality adjusted approach is conceived to distinguish between households who can afford housing with a given income level within the ambit of $30 \%$ of income and those who cannot afford.

\subsection{Housing Affordability Index}

In the most developed countries of the world, Housing Affordability Index is used to determine Housing affordability levels. Affordability Index measures whether or not a typical family could qualify for a mortgage loan on a typical home. A higher index ratio indicates more affordability. Two commonly used Affordability Indexes are:

\section{i. The Composite Housing Affordability Index (HAI)}

This Index measures median household income relative to the income needed to purchase a median priced house. In other words, the index measures whether or not a typical family could qualify for a mortgage loan on a typical home. According to the Federal Bank of San Francisco (2003), the Composite Housing Affordability Index provides a way to track over time whether housing is becoming more or less affordable for the typical household. Components of the index are house prices, interest rates and income. This Housing Affordability Index assumes a down payment of $20 \%$ of the home price and a maximum mortgage repayment of $25 \%$ of the gross monthly income of the household. It is published monthly by the National Association of Realtors. A higher HAI ratio indicates relatively more affordability. 


\section{ii The California Housing Affordability Index}

The California Housing Affordability Index tracks the percentage of California and National households that can afford to purchase a median priced single family house. Upon computation, the percentage of households with incomes greater than or equal to the minimum qualifying income is the Housing Affordability Index (California Association of Realtors, 2014). The California Housing Affordability Index also assumes a down payment of $20 \%$. It further assumes monthly property taxes to be $1 \%$ of the medium sales price divided by 12 , while monthly insurance payments on the house are assumed to be $0.38 \%$ of the median home sales price divided by 12.

\subsection{Literature Review}

Over the years, so much work has been done world over to address the problems of housing affordability with Nigeria inclusive. Some authors like Kabir and Bustani (2009) and Aribigbola (2013) among othershave evaluated government efforts in a bid to tackle these problems. Others were interested in examining parameters for measuring affordability while some were keen on exploring the most suitable means of delivering affordable housing. For instance, Onyike (2007) carefully studied the situation of housing affordability in Owerri, Nigeria and explained the impact of the monetization of fringe benefits (residential accommodation, transport facilities, medical services and utilities such as electricity, water, and telephone) on the civil servants ability to own personal houses in the state. The results showed that levels 13 and above, and level 17 of the state and federal civil servants respectively were able to have access to what may be adjudged as decent housing. He further observed that majority of public servants in the state cannot afford adequate housing without substantial assistance from the government.

Aribigbola (2008) in his study of housing affordability as a factor in the creation of sustainable environment in the developing world, used data generated through a systematic survey of households within the nine political wards of Akure; The study aimed at assessing the extent of the problem of housing affordability and how it affects the creation of a sustainable built environment. Results revealed that affordability is a major problem and poses serious challenges to sustainable development of the built environment, hence it was recommended that institutional framework to promote, enhance and encourage affordable housing provision should be created in the city. Ndubueze (2009) concerned his work with the different affordability measurement approaches in order to carefully examine the nature of urban housing. Meanwhile, Nicholas (2010) explored the affordable housing situation in Ghana using Kumasi and Tamale as study areas, and reported that there are insufficient affordable housing units in Ghana, while the available units are poorly developed and are not habitable. The study further evaluated the affordable housing delivery system in Ghana and it was discovered that housing units with basic acceptable standards are unaffordable by many households in the study areas. Moreover, majority of the households in Kumasi and Tamale cannot afford mortgage credit, and adequate rented and owner occupied housing units because of their low income level, high unemployment rate, and high interest rates.

Udoekanem (2011) examined the financing of affordable housing through commercial bank real estate loans in Niger State; the study provided evidence that 90 per cent of the households in Minna cannot afford loans granted by commercials banks. Analysis also showed that the maximum they could repay through their salaries was one - third or $33.33 \%$ of their monthly salary which was even below what is required to offset a loan that will enable them acquire a 2 bedroom bungalow within residential neighbourhoods in suburb areas of the city, thus making the real estate loans from commercial banks unaffordable by the civil servants inclusive of those on a higher grade levels.From a global perspective, Pittini (2012) submitted that the current trend of housing affordability in European Union (EU) is not far from what is obtainable in most parts of the world. Findings from this study showed that on the average $33.8 \%$ of Europeans feel that they are experiencing disproportionate housing costs. The common perception in the European countries is that housing affordability has become much worse compared to previous years and was expected to further decrease in 2012. Moreover, cost of decent accommodation is particularly difficult in capitals and large cities. On the average, costof housing for the overall EU 27 population amounted to $22.5 \%$ of disposable income (Pittini, 2012).

It is however important to note that the most acceptable definition ofhousingaffordability which puts it at not more than $30 \%$ of household income was vigorously criticized by Eric et al. (2005) as it does not account for the trade- offs (sacrifices) households concedes to in order to achieve a lower cost of housing. This means that not everyone spending more than a certain percentage of their income actually have housing problem; for instance, a household might be spending less than $30 \%$ of its income on housing, but lives in a neighbourhood of poor quality and incur additional cost for transportation to work place, while another household for sentimental reasons (change in social class, change in taste and status) spends more than $30 \%$ of its income on housing. This 
does not translate into affordability problem since it is a thing of choice. Lau (2001) opined that a household can only be said to have housing affordability problem if after paying housing costs which meets the socially-accepted norms of adequate housing standards, are unable to meet up with the living standard of those staying in social housing. HUD (2005) as cited in Aribigbola (2008) however argued that families who pay more than $30 \%$ of their income on housing are considered cost burdened and may have difficulty affording necessities such as food, clothing, transportation and medical care.Based on this, this study seeks to establish if federal civil servants in Minna are able to pay for their housing need and still meet up with their other basic needs. These are analysed by adopting the 30\% measuring standardusing the Rent- to- income ratio (RIR) and House Price-to-income ratio (PIR) as affordability measuring indexto adequately report the current affordability situation in the state capital. Rent-to-income ratio is an expression of rent as a percentage of income, meaning the portion of the household's annual income expended on housing consumption within a given period of time. Whereas the House price- to-income ratio is that percentage or fraction of the total income of a household to the price of the housing unit. This strategy is considered capable of reflecting rapid changes in affordability conditions across time and has a comparability quality.

\section{Methodology}

The relevant population comprised of federal civil servants drawn from 15 randomly selected Federal Government Parastatals and Agencies in Minna. A total of 200 workers spreading across all grade levels that are also breadwinners of their respective households and occupy rented apartments were purposively sampled for the study. Workers in the sampled organizations/parastatals were categorized into higher, middle and lower cadres based on their income levels which also spread across, from the highest paid officer to the least paid officer. Questionnaire were employed and used to generate the primary data. These included data on the annual income of respondents, house type, rents paid andcost of houses purchased among others. Secondary data were obtained from the records of Estate Surveyors and Valuers on rental and capital values of properties within Minna metropolis.Simple descriptive statistics, Pearson Product Moment Correlation, likert scale and Relative Index were used to analyse the collected data. Results from analysis are presented in form of charts and frequency tables.This study further determined housing affordability levels in the study area using the Composite housing affordability index to measure whethera typical family could qualify for a mortgage loan on a typical single family house or not. The California housing affordability index was also adopted to measure the percentage of households in the study area that can afford to purchase a median priced single family house.

\section{Results and Disscussion}

\subsection{Cadres of the Respondents}

The sampled respondents were categorised into three cadres using their annual emoluments as a basis. It covers all levels of workers, from the least paid to the highest paid.

Table 1. Distribution of respondents according to assigned cadres

\begin{tabular}{lll}
\hline Cadre & No.of Staff Sampled & Percentage \\
\hline Higher Cadre & 24 & $12 \%$ \\
Middle Cadre & 103 & $51.5 \%$ \\
Lower Cadre & 73 & $36.5 \%$ \\
Total & $\mathbf{2 0 0}$ & $\mathbf{1 0 0 \%}$ \\
\hline
\end{tabular}

Source: Author's field survey.

Table 1 shows the distribution of respondents according to assigned cadres. It shows that $12 \%$ are on the higher cadre, while $51.5 \%$ and $36.5 \%$ are on the middle and lower cadres respectively.

\subsection{Residential Properties Commonly Occupied by Federal Civil Servants in Minna}

Federal civil servants in Minna occupy various types of residential accommodation, common types being single room apartments, one bedroom, two bedroom and three bedroom flats. These were however majorly attributed to the costs of paying for these types of houses. 


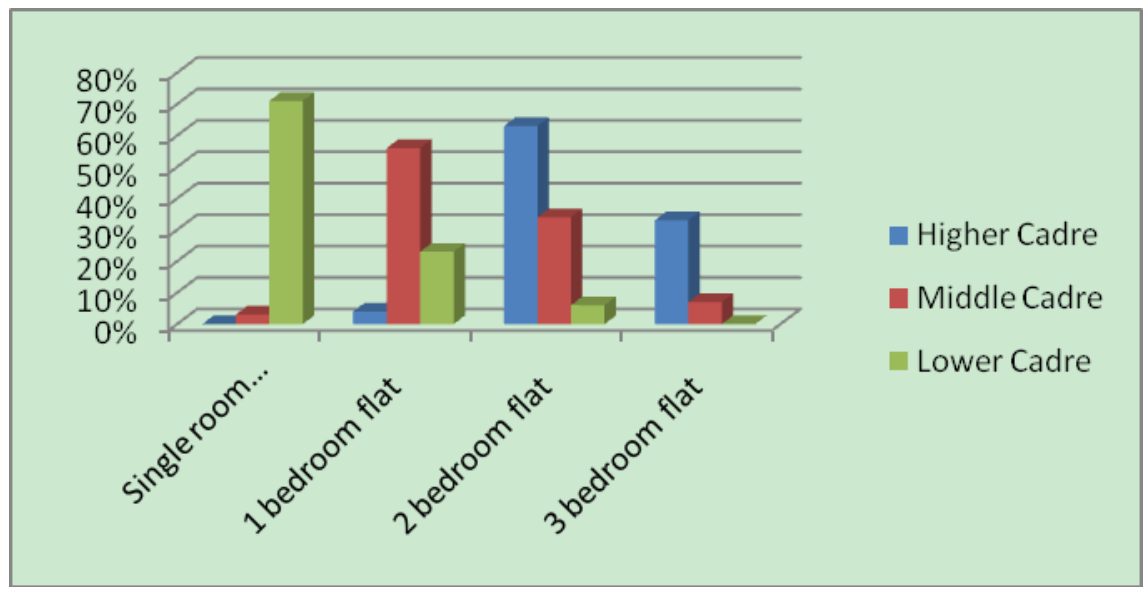

Figure 1. Showing types of residential properties commonly occupied by federal civil servants in Minna Source: Author's field survey.

Figure 1 show the types of residential properties commonly occupied by federal civil servants in Minna. It shows that $3 \%$ and $71 \%$ of respondents in the middle and lower cadres respectively occupy single room apartments. No staff in the higher cadre occupy single room apartment. Similarly, $4 \%, 56 \%$ and $23 \%$ in the higher, middle and lower cadres respectively occupy one bedroom flats. In the same vein, $63 \%, 34 \%$ and $6 \%$ in the three cadres respectively occupy two bedroom flats, while $33 \%$ and $7 \%$ in the higher and middle cadres respectively occupy three bedroom flats.

These residential properties are spread across various locations in Minna. Data gathered however revealed that a larger proportion of federal civil servants reside in Tunga, Bosso, Maitumbi, Maikunkele, Dutsenkura and Barkin sale areas, all having varied housing and environmental conditions. It further revealed that a larger proportion of federal civil servants in the higher cadre reside in Dutsenkura and Tunga areas, while a sizeable proportion of those in the middle cadre reside in Tunga, Bosso and Maitumbi areas. In the same vein, a sizeable proportion of those in the lower cadre reside in Bosso, Maitumbi, Maikunkele and Barkin-sale areas.

Table 2. Average rental values of property types in some locations in Minna

\begin{tabular}{lllll}
\hline Property Location & \multicolumn{4}{l}{ Average Rental Values in N '000 } \\
& $\begin{array}{l}\text { Single room } \\
\text { apartment }\end{array}$ & 1 Bedroom Flat & 2 Bedroom Flat & 3 Bedroom Flat \\
\hline Dutsen Kura & 60 & 90 & 150 & 230 \\
Tunga & 80 & 110 & 250 & 300 \\
Bosso & 60 & 100 & 200 & 250 \\
Barkin-sale & 55 & 110 & 150 & 250 \\
Maitumbi & 55 & 80 & 150 & 220 \\
Chanchaga & 40 & 70 & 120 & 200 \\
Maikunkele & 30 & 60 & 100 & 180 \\
\hline
\end{tabular}

Source: Author's field survey.

Table 2 shows the average rental values of types of residential accommodation commonly occupied by federal civil servants in varied locations in Minna. These values vary from $\$ 30,000$ for single room apartments to $\$ 300,000$ for three bedroom flats.

\subsection{Annual Income and Housing Affordability}

Analysis of how Annual income influences housing affordability in shown below. 
Table 3. Average annual income of Federal Civil Servants on Grade levels 3 to 17

\begin{tabular}{lll}
\hline & Grade Level & Averageannual income (\$) \\
\hline Lower Cadre & 3 & 261,324 \\
& 4 & 281,472 \\
5 & 320,668 \\
& 6 & 390,962 \\
& 7 & 638,433 \\
\hline Middle Cadre & 8 & 811,623 \\
& 9 & 955,877 \\
& 10 & $1,108,273$ \\
& 12 & $1,269,050$ \\
Higher Cadre & 13 & $1,403,043$ \\
& 14 & $1,542,971$ \\
& 15 & $2,060,078$ \\
& 16 & $2,538,125$ \\
& 17 & $4,807,068$ \\
\hline
\end{tabular}

Source: National Salaries, Incomes and wages Commission (2010).

Table 3 shows the average annual income of federal civil servants on grade levels 3 to 17 . Civil servants on these grade levels were however further classified into lower, medium and higher cadres.

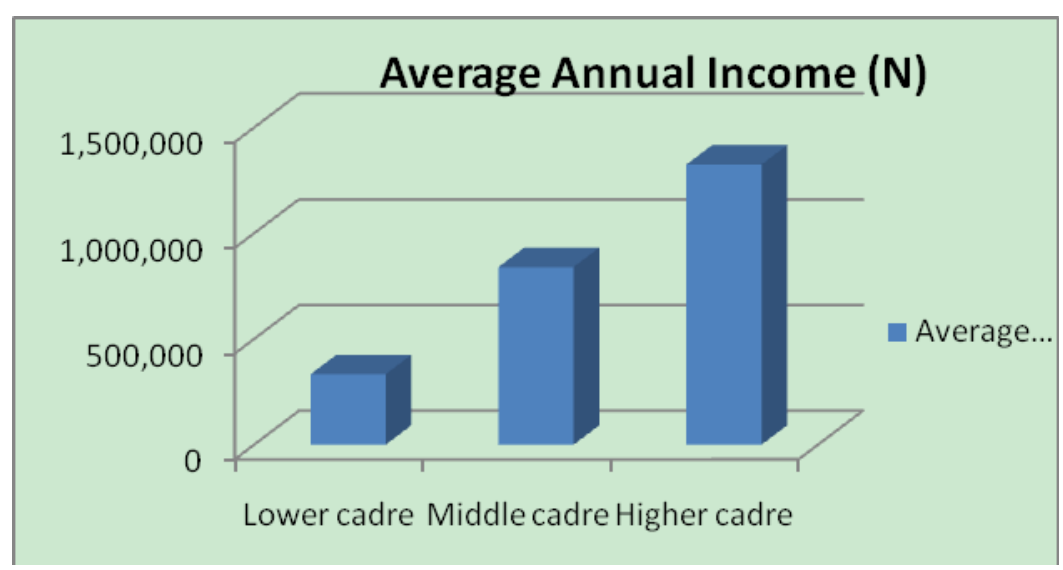

Figure 2. The average annual income of federal civil servants in the three cadres

Source: Author's field survey.

Figure 2 shows the average annual income of respondents in the three cadres. It shows that those on the lower cadre earn an average annual income of $\$ 378,527$ while those on the middle and higher cadres earn an average of $\$ 1,109,573$ and $\$ 2,737,060$ respectively per annum.

Table 4. Modal class of rents paid by Federal Civil Servants in the three cadres

Source: Author's field survey.

\begin{tabular}{ll}
\hline Cadre & Annual Rents paid ( $)$ \\
\hline Lower cadre & $50,000-90,000$ \\
Middle cadre & $100,000-150,000$ \\
Higher cadre & $200,000-250,000$ \\
\hline
\end{tabular}

Table 4 shows the rents paid by majority of civil servants in the three cadres. Here, the annual rents paid by the respondents in all cadres were collated and grouped into appropriate intervals, and the modal class of these values adopted independently for all cadres. These values give a clear presentation of how much is paid as rents by a substantial number of civil servants in the lower, middle and higher cadres. 
Table 5. Rent to income ratio of Federal Civil Servants in Minna

\begin{tabular}{llll}
\hline Cadre & Annual rental value ( $)$ & $\begin{array}{l}\text { Average annual income } \\
(\#)\end{array}$ & $\begin{array}{l}\text { Percentage of income spent on } \\
\text { housing }\end{array}$ \\
\hline Lower Cadre & $50,000-90,000$ & 378,572 & $13.2 \%-23.8 \%$ \\
Middle Cadre & $100,000-150,000$ & $1,109,573$ & $9 \%-13.5 \%$ \\
Higher Cadre & $200,000-250,000$ & $2,737,060$ & $7.3 \%-9.1 \%$ \\
\hline
\end{tabular}

Source: Author's field survey.

Table 5 shows the rent to income ratio of federal civil servants in Minna. It shows that federal civil servants on the lower cadre spend $13.2 \%-23.8 \%$ of their annual income on rents. Similarly, those on the middle and higher cadres spend $9 \%-13.5 \%$ and $7 \%-9.1 \%$ of their annual income on rents respectively. However, the percentage of income spent on housing can be greatly affected by changing economic situations in Nigeria. This implies that a periodic upward review of rent without a corresponding increase in annual salaries will result in an increase in the percentage of household income spent on rent.

\subsection{Predominant Factors Influencing Choice of Residential Accommodation}

Certain factors were identified as having influenced the choices of residential accommodation by the respondents. The various opinions of respondents were weighed using the likert scale and the consensus opinions are shown in Table 6.

Table 6. Factors influencing choice of residential accommodation by federal civil servants in Minna

\begin{tabular}{lllll}
\hline Factors & Sum & Mean & $\begin{array}{l}\text { Relative } \\
\text { Index }\end{array}$ & Consensus opinions \\
\hline Household size & 691 & 3.46 & 0.69 & Undecided \\
Level of income & 962 & 4.81 & 0.96 & Strongly agree \\
Size of housing unit & 793 & 3.97 & 0.79 & Agree \\
Security & 821 & 4.11 & 0.82 & Agree \\
Proximity to place of work & 654 & 3.27 & 0.65 & Undecided \\
Availability of Infrastructure & 727 & 3.64 & 0.73 & Agree \\
Availability of services & 802 & 4.01 & 0.80 & Agree \\
\hline
\end{tabular}

Source: Author's field survey.

Interestingly, data in Table 6 reveals that respondents strongly agree that their various levels of income (with highest relative index of 0.96) influence their choice of residential accommodation. This is undoubtly the almost singular factor that impact on preference of Federal Civil Servants for residential accommodation in the study area. They agree that other influencing factors ranked between $0.65-0.82$ are size of housing unit, security, as well as availability of basic infrastructure and services such as water and electricity.

\subsection{The Relationship between Annual Income and Residential Property Rental Values}

The Pearson Product Moment Correlation was used to test the relationship between the annual income of respondents and the rental values of properties occupied by them. Results revealed a strong positive correlation between annual income and the rental values of residential properties occupied by federal civil servants in Minna. Responses from respondents further revealed that federal civil servants in Minna can averagely afford to pay rents for certain types of houses as a result of their income, irrespective of their family size, the quality of such houses, and nearness to place of work.

\subsection{Level of Satisfaction with Rented Housing Accommodation}

Respondents in the study area expressed varied levels of satisfaction with the rented apartments they occupy. These are shown in Figure 3. 


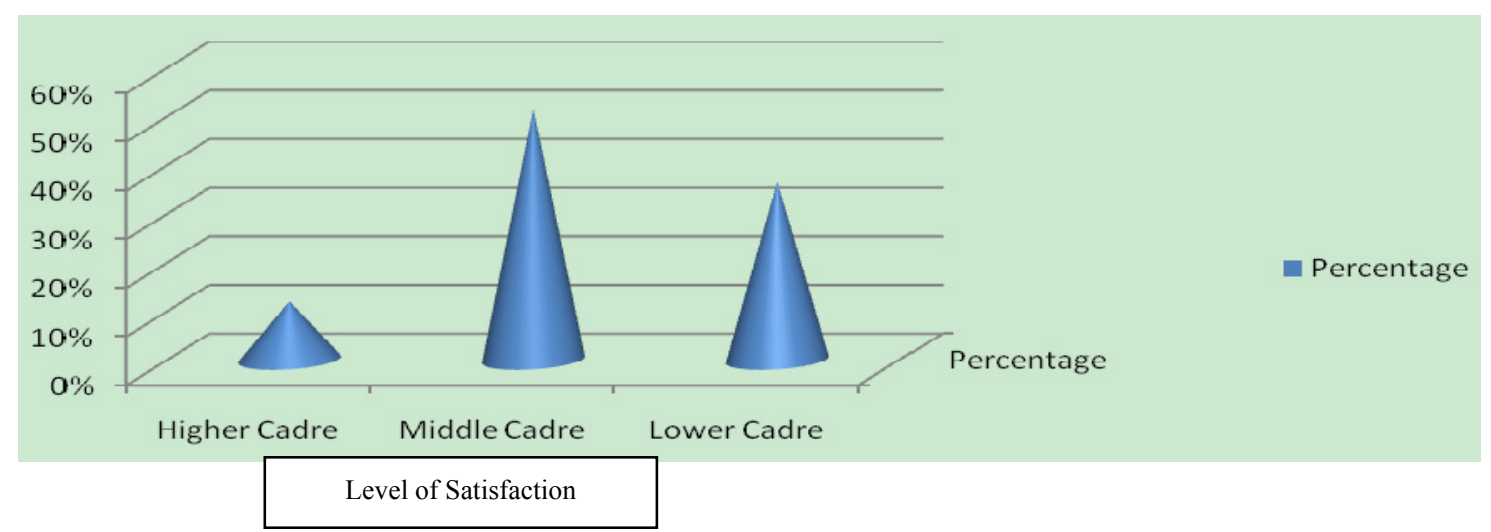

Figure 3. The level of satisfaction with rented houses occupied by Federal Civil Servants in Minna

Source: Author's field survey.

Figure 3 shows respondents' level of satisfaction with the rented apartments they occupy. It shows that $10 \%$ of respondents are very satisfied with the houses they occupy, $31 \%$ are satisfied while $59 \%$ are not satisfied.

118 respondents representing $59 \%$ of the sampled civil servants who were not satisfied with their rented housing attributed it to factors such as poor housing quality, densely populated neighbourhoods, small size of housing units, long distance to work place and high cost of rents.All the sampled civil servants desired to own houses of their own, and further expressed likeness for at least two bedroom flats in decent neighbourhoods.

\subsection{Annual Income as a Percentage of House Prices}

Since all the sampled civil servants desired to have their own houses, this research further sought to establish the implication of this on affordable housing in the study area. This was achieved by assessing the capital values of residential property types in Minna and the average annual income of Federal Civil Servants. This research however adopted the sales values of a recently completed public housing estate in the surburb of minna as a yard stick. In the said estate, a two bedroom flat recently sold for $\$ 3,700,000$ while a three bedroom flat was sold for $¥ 4,800,000$

Table 7. Average annual income as a percentage of house prices in Minna

\begin{tabular}{|c|c|c|c|}
\hline Cadre & Capital values (\#) & Average annual income ( & $\begin{array}{l}\text { Annual income as a percentage of } \\
\text { House price }\end{array}$ \\
\hline Lower Cadre & $\begin{array}{ll}\text { i. } & 3,700,000 \\
\text { ii. } & 4,800,000 \\
\end{array}$ & 378,572 & $\begin{array}{ll}\text { i. } & 10 \% \\
\text { ii. } & 8 \% \\
\end{array}$ \\
\hline Middle Cadre & $\begin{array}{ll}\text { i. } & 3,700,000 \\
\text { ii. } & 4,800,000 \\
\end{array}$ & $1,109,573$ & $\begin{array}{ll}\text { i. } & 30 \% \\
\text { ii. } & 23 \% \\
\end{array}$ \\
\hline Higher Cadre & $\begin{array}{ll}\text { i. } & 3,700,000 \\
\text { ii. } & 4,800,000 \\
\end{array}$ & $2,737,060$ & $\begin{array}{ll}\text { i. } & 74 \% \\
\text { ii. } & 57 \% \\
\end{array}$ \\
\hline
\end{tabular}

Source: Author's field survey.

Table 7 shows the average annual income of respondents as a percentage of house prices in Minna. It shows that the annual income of civil servants in the lower cadre is just $8 \%$ of the cost of a three bedroom flat and $10 \%$ of the cost of a two bedroom flat. In the same vein, the annual income of civil servants in the middle and higher cadres is $30 \%$ and $74 \%$ the cost of a two bedroom flat; and $23 \%$ and $57 \%$ of the cost of a three bedroom flat respectively.

Due to the capital intensive nature of housing development, it will be almost impossible for staff in the three cadres to comfortably purchase houses from their annual emoluments. This is particularly true for staff in in the lower cadre. 


\subsection{Housing Affordability Index}

The Composite Housing Affordability Index (HAI) and the California Housing Affordability Index were adopted in this study to determine housing affordability levels in the study area. This is in line with recent trends in the most developed countries of the world.

\subsubsection{The Composite Housing Affordability Index (HAI)}

This Index measures median household income relative to the income needed to purchase a median priced house. In other words, the index measures whether or not a typical family could qualify for a mortgage loan on a typical home.It is important to note that for the purpose of this study, the sales value of a recently completed public housing estate in the surburb of minna was adopted, thus:

i. A typical home is the median priced single family home in the said estate

ii. A typical family is one earning the median family income in the study area

iii. The prevailing mortgage interest rate is the effective rate of housing loans from the Federal Mortgage Bank of Nigeria.

Table 8. Housing affordability index in the study area

\begin{tabular}{lllllll}
\hline Month/Year & $\begin{array}{l}\text { Median Priced } \\
\text { exsiting single } \\
\text { family home }\end{array}$ & $\begin{array}{l}\text { Mortgage } \\
\text { Rate }\end{array}$ & $\begin{array}{l}\text { Monthly P\&I } \\
\text { Payment }\end{array}$ & $\begin{array}{l}\text { Payment as a } \\
\text { \% of income }\end{array}$ & $\begin{array}{l}\text { Median } \\
\text { Income }\end{array}$ & $\begin{array}{l}\text { Family } \\
\text { Qualifying } \\
\text { Income } \\
\text { Affordability } \\
\text { Index }\end{array}$ \\
\hline July 2014 & $3,700,000$ & 6 & $17,746.68$ & 19.19 & $1,109,573$ & $851,840.64$ \\
Aug. 2014 & $3,700,000$ & 6 & $17,746.68$ & 19.19 & $1,109,573$ & $851,840.64$ \\
Sept. 2014 & $3,700,000$ & 6 & $17,746.68$ & 19.19 & $1,109,573$ & $851,840.64$ \\
\hline
\end{tabular}

Source: Author's Field Survey.

Table 8 shows the Composite Housing Affordability Index for the study area in the third quarter of 2014. It presents an index of 130.26 which indicates that a typical family has more income than necessary to purchase a typical house. This implies that the typical household income was about $30.26 \%$ above the income necessary to qualify for a mortgage loan on the typical home.

\subsubsection{The California Housing Affordability Index}

The California Housing Affordability Index measures the percentage of California and National households that can afford to purchase a median priced single family house.Here, the minimum annual income needed to qualify for a loan on a median priced home is compared to the income distribution of households. Thus Housing Affordability index is represented by the percentage of households with incomes greater or equal to the minimum income needed to qualify for a loan. Results of computations in the study area are presented as follows:

Table 9. California housing affordability index in the study area

\begin{tabular}{ll}
\hline Total monthly payment & $22,001.68$ \\
Minimum qualifying income & $73,338.93$ \\
Minimum qualifying annual income & $880,067.16$ \\
$\%$ of households with income greater or equal to minimum & $63.5 \%$ \\
qualifying annual income & \\
Housing Affordability index in Minna & 63.5 \\
\hline
\end{tabular}

Source: Author's Field Survey.

Table 9 shows computations of the California Housing Affordability Index in the study area. It indicates an affordability index of 63.5 , which implies that $63.5 \%$ of households (Federal Civil Servants) in the study area can afford to purchase a two bedroom flat in a public estate in the surburb of Minna.

\section{Conclusion and Recommendation}

The study has examined housing affordability by federal civil servants in Minna.It successfully established the percentage of annual income spent on rents by federal civil servants and further expressed their annual income as 
a percentage of house prices in the study area. Findings revealed that federal civil servants in Minna can averagely afford to pay for rented accommodation because they spend less than $30 \%$ of their annual income on rents. The pertinent question however is, whether what is left after paying rents is sufficient to adequately take care of other non-housing needs. The study further revealed a composite housing affordability index of 130.26 and a California housing affordability index of 63.5, thus, Housing in the study area can be said to be relatively affordable.

Interestingly, all the respondents desired to have their own houses, thus, in order to ensure that federal civil servants in Minna have access to decent and comfortable housing, a Home Ownership Model (HOM) have been developed which can enable workers purchase or build their own houses and pay conveniently while also ensuring that other non-housing needs are met.It simply requires civil servants to contribute to the National Housing Fund (NHF) and subsequently seek for National Housing Fund Loan from the Federal Mortgage Bank of Nigeria through a Primary Mortgage Institution (PMI) of his/her choice in accordance with the National Housing Fund (NHF) Law of 1992. The loan amount as well as the re-payment period of this loan will however be a function of the civil servant's number of years in service, age and salary; mathematically represented as:

$$
\text { HO }=\text { NHFL } \rightarrow \text { (f) NAS }
$$

$$
\begin{aligned}
\text { Where, HO } & =\text { Home Ownership } \\
\text { NHFL } & =\text { National Housing Fund Loan } \\
\text { NAS } & =\text { Number of years in Service, Age and Salary. }
\end{aligned}
$$

For the model to work effectivelythere is the need for civil servants to own and operate a bank account with any PMI of their choice because this is one of the basic requirements in seeking for the NHF loan. There is also the need to calculate and know the total contributions of each civil servant to the National Housing Fund (NHF). Total contributions here are simply the accumulated $2.5 \%$ of a worker's monthly basic salary deducted on monthly basis. It is also recommended that the government at all levels embark on mass housing projects to adequately take care of the increasing housing demand in the study area.

\section{References}

Andrews, O. N. (1998). Trends in the Supply of Affordable Housing Meeting America's Housing Needs (MAHD): A Habitat 11 Follow-up Project.

Aribigbola, A. (2008). Housing Policy Formulation in Developing Countries: Evidence of Programme Implementation from Akure, Ondo State, Nigeria. Journal of Human Ecology, 23(2), 125-134.

Aribigbola, A. (2011). Housing Affordability as a Factor in the Creation of Sustainable Environment in Developing World: The Example of Akure, Nigeria. Journal of Human Ecology, 35(2), 121-131.

Aribigbola, A. (2013). Causes and Consequences of Housing Policy Failure in Nigeria. British Journal of Social Sciences, 1(6).

Aribigbola, A., \& Ayeniyo, O. I. (2012). Site - And - Services Strategy for Achieving Adequate Housing in Nigeria in $21^{\text {st }}$ Century. International Journal of Humanities and Social Science, 2(2).

Ayeniyo, O. (2011). Challenges and Strategies for Affordable Housing Ownership for the Nigerian Urban Poor. African Nebula, 4, 28-35.

Califonia Association of Realtors. (2014). Retrieved from http://www.car.org

Federal Reserve Bank of Sanfrancisco. (2003). How is the Housing Affordability Index Calculated? Retrieved from www.frbsf.org/education/publications/doctor-econ/2003/december/housing-affordability-index

Gbadeyan, R. A. (2011). Private Sector's Contributions to the Development of the Nigerian Housing Market. Current Research Journal of Social Sciences, 3(2), 104-113.

Ibem, E. O., \& Amole, O. O. (2010). Evaluation of Public Housing Programmes in Nigeria: A Theoretical and Conceptual Approach. The Built \& Human Environment Review, 3, 88-117.

Jinadu, A. M. (2007).Understanding the Basis of Housing. Jos: University Press.

Kabir, B., \& Bustani, S., A. (2009). A Review of Housing Delivery Efforts in Nigeria. Department of Building, Faculty of Environmental Design.Ahmadu Bello University, Zaria, Nigeria.

Lau, K., Y., \& Leung, B. (2001). Comparison of Indicators Used In Measuring Housing Affordability in Hong Kong and Their Validity. Working Paper Series 2001/No.2, Department of Public and Social Administration, City University of Hong Kong. 
Ndubueze, O. J. (2009). Urban Housing Affordability and Housing Policy Dilemma in Nigeria. A Thesis Submitted to the University of Birmingham for the degree of Doctor of Philosophy, Centre for Urban and Regional Studies, School of Public Policy. Retrieved from http://etheses.bham.ac.uk/298/1/Ndubueze09PhD.pdf

Nicholas, B. A. (2010). Housing Affordability in Ghana: A Focus on Kumasi and Tamale. Ethiopian Journal of Environmental Studies and Management, 3(3).

Onyike, A. J. (2007). An Assessment of the Affordability of Housing by Public Servants in Owerri Nigeria. Journal of Land Use and Development Studies, 3(1), 21-34.

Pittini, A. (2012). Housing Affordability in the Eu: Current Situation and Recent Trend. Research Briefing CECODHAS Housing Europe's Observatory.

Udoekanem, N. B. (2011). Financing Affordable Housing in Niger State of Nigeria through Commercial Banks: Trends, Issues and Future Directions. Social and Management Research Journal, 8(85).

\section{Copyrights}

Copyright for this article is retained by the author(s), with first publication rights granted to the journal.

This is an open-access article distributed under the terms and conditions of the Creative Commons Attribution license (http://creativecommons.org/licenses/by/3.0/). 